\title{
The Role of Dermatologists in HPV Discovery and Their Pioneer Ideas of Vaccination: From Hans Biberstein through Stefania Jablonska to Harald zur Hausen
}

\author{
Barbara Gasior-Chrzan* \\ Department of Dermatology, The Arctic University of Tromsø, Norway
}

\section{Vaccines}

Since Mars 2020 we are living in a pandemic, because of SARSCoV-2. This situation reminds us of epidemics (pestilences) from past times and forces us to change our behavior. We put on our masks and we sneak at the recommended distance, avoiding each other. The sale of disinfectants has increased enormously. In the past, great censers were lit in churches as a measure against plague and the church rooms were filled with aromatic smoke. Through the towns and villages, processions moved around with a cross at the front, banners and people pleaded while singing: "Save us from air, hunger, fire and war, Lord". Today we trust vaccines to stop the pandemic. The invention of vaccines was a pivotal moment in the history of medicine.

British physician Edward Jenner (1796) and Frenchmen Louis Pasteur (1885) are vaccines pioneers and we can not imagine our liv without them. In course of time was coming vaccines against many diseases.

Infection of the genital tract with human papilloma viruses (HPV) is a common occurrence and manifestations can include genital warts, dysplasia and carcinomas. Frequent association HPV with anogenital carcinomas are strongly indicators of their important role in carcinogenesis and it has raised speculations about possible cancer prevention by vaccination against HPV [1,2].

The idea of producing a vaccine against HPV has been pioneered by Hans Biberstein $(1889$ - 1965). He was a part of Josef Jadassohn's department in Breslau (now Wroclaw, Poland). He and his Jewish colleges were forced by NASI regime, to leave Germany. He went to US where he had been appointed to an academic position at the New York Skin and Cancer Unit of the New York Postgraduate Medical School. The great field of Biberstein interest was research on viral warts with the goal of developing a vaccine. He did put together a sterile vaccine out of material from human warts (plane, common warts and condylomata aacuminata) and treated 112 patients with intracutaneous injections. After more than 10 injections, $75 \%$ of patients experienced a therapeutic effect, often with complete or almost complete resolution. Biberstein compared the drying up of the warts with changes shown by "butter in a frying pan". All clinical variants seemed to respond equally, supporting his hypothesis that they had a common etiology.

The therapeutic effect was also dependent of the source of the material used for the vaccine. Injections prepared from warts that had been therapy resistant appeared to be clinically more effective. Biberstein [3] suggested that "there are a variety of strains of virus differing in their immunizing qualities". He reviewed his work 20 years after the original publication, responding to criticism [4]. His early attempts and insights are particularly relevant today with the availability of several effective human papillomavirus vaccines.
Stefania Ginburg-Jablonska, a famous polish dermatologist from Warszawa, Poland, was first to discover the connection between HPV and skin cancer in epidermodysplasia verruciformis in 1972 [5]. In 1978 the team Gerhard Orth, from the Pasteur Institute of France, and Jablonska discovered the specific strain of HPV virus responsible for skin cancer [6]. For this achievement, both received the Robert-KochPrize in Bonn.

In 1976, Harald zur Hausen, a german scientist and virologist, published his famous hypothesis on HPV. Together with L. Gissmann, he explored the association of HPV with cervical cancer [7]. During 1983 [8] and 1984 he and his team discovered two strains of HPV: HPV 16 DNA in cervical cancer cells and warts and HPV 11 and showed that these strains of HPV were the cause of cervical cancer [8]. The findings led to the development of two preventive vaccines against HPV 16 and HPV 18 Gardasil and Cervarix, which are responsible for $90 \%$ of genital warts [9].

For this discovery, Harald zur Hausen won the Nobel Prize in Physiology and Medicine in 2008.

\section{References}

1. Wieland U, Pfister H (1997) Papilloma viruses in human pathology: epidemiology, pathogenesis and oncogenic role. Gross GE, Barrassco R (Eds), Human papilloma virus infection: a clinical atlas. Ullstein pp: 1-18.

2. Onon TS (2011) History of human papillomavirus, warts and cancer: What do we know today? Best Pract Res Clin Obstet Gynaecol 25: 565-74. [Crossref]

3. Biberstein H (1944) Immunization therapy of warts. Arch Derm Syphilol 50: 12-24.

4. Biberstein H (1964) Zur Kritikk der Immunotherapie der Warzen und Kondylome. Hautarzt 5:161-162

5. Jablonska S, Dabrowski J, Jakubowicz K (1972) Epidermodysplasia verruciformis as a model in studies on the role of papovaviruses in oncogenesis. Cancer Res 32: 583-589 [Crossref]

6. Orth G, Jablonska S, Favre M, Croissant O, Jarzabek-Chorzelska M, et al (1978) Characterization of two types of human papillomaviruses in lesions of epidermodysplasia verruciformis. Proc Natl Acad Sci USA 75: 1537-41 [Crossref]

7. Gissmann L, Pfister H, zur Hausen H (1977) Human papilloma viruses (HPV) characterisation of four different isolates. Virology 76: 569-580 [Crossref]

*Correspondence to: Barbara Gasior-Chrzan, Department of Dermatology, The Arctic University of Tromsø, Norway, E-mail: bga000@post.uit.no

Key words: human papillomavirus, vaccination, hans biberstein, stefania jablonska, barald zur hausen

Received: July 19, 2021; Accepted: July 26, 2021; Published: July 29, 2021 
Gasior-Chrzan B (2021) The Role of Dermatologists in HPV Discovery and Their Pioneer Ideas of Vaccination: From Hans Biberstein through Stefania Jablonska to Harald zur Hausen

8. Durst M, Gissmann L, Ikenberg H, zur Hausen H (1983) A papillomavirus DNA from a cervical carcinoma and its prevalence in cancer biopsy samples from different geografic regions. Proc Natl Acad Sci USA 80: 3812-381.5 [Crossref]
9. Borysiewicz LK, Fiander A, Nimako M, Man S, Wilkinson GW, et al. (1996) A recombinant vaccinia virus encoding human papillomavirus types 16 and 18. E 6 and E 7 proteins as immunotherapy for cervical cancer. Lancet 347: 1523-1527. [Crossref]

Copyright: $\mathbb{0} 2021$ Gasior-Chrzan B. This is an open-access article distributed under the terms of the Creative Commons Attribution License, which permits unrestricted use, distribution, and reproduction in any medium, provided the original author and source are credited. 